Volume 2, Nomor 2, 2019, hlm. 181-196

P-ISSN: 2622-2280 | E-ISSN: 2622-4658

https://ejurnal.iiq.ac.id/index.php/alfanar

DOI:10.33511/alfanar.v2n2.181-196

\title{
Respon Al-Quran dalam Menyikapi Berita Hoax
}

Studi Analisis Tafsir Tematik

Chalimatus Sa'dijah

IIQ Jakarta

fegamahdavi@gmail.com

\begin{abstract}
This article aims to analyze the Qur'an's response in responding to hoax news. hoax information dissemination on social media is a phenomenon that threatens ukhuwah Islamiyah in the nation and state. The existence of hoax content in the universe of social media has a significant negative impact that has succeeded in making the community divided, such as making proactive content, propaganda, turning facts around. The author uses the maudhu'i method as the blade of his analysis. The results of this study conclude that God condemns the perpetrators of hoaxes spreaders. The Koran also recommends always telling the truth. He is the act of those who obey God. By maintaining the correct words, the spread of hoaxes will be increasingly minimal. Furthermore, besides saying the truth, the Koran and the hadith also instructed Muslims to always do tabayyun or clarification of the arrival of the news. Even this clarification is also very directed at religious leaders to always oversee the arrival of the news and clarified the truth.
\end{abstract}

Keywords: Hoax, social media, Al-Qur'an

\begin{abstract}
Abstrak
Artikel ini bertujuan menganalisa respon Al-Qur'an dalam menyikapi berita hoax. Penyebaran informasi hoax di media sosial merupakan fenomena yang mengancam ukhuwah Islamiyah dalam berbangsa dan bernegara. Keberadaan konten-konten hoax di jagad media sosial memberikan dampak negatif yang signifikan yang berhasil membuat masyarakat terbelah, seperti membuat kontenkonten profokatif, propaganda, memutar balikkan fakta. Penulis menggunakan metode maudhu'i sebagai pisau analisisnya Hasil penelitian ini menyimpulkan bahwa Allah mengecam terhadap para pelaku penyebar hoax. Al-Qur'an juga menganjurkan untuk selalu berkata benar. Ia merupakan perbuatan orangorang yang patuh kepada Allah. Dengan menjaga perkataan yang benar, maka penyebaran hoax akan semakin minim. Selanjutnya selain berkata benar, AlQuran dan hadis juga menyuruh umat Islam untuk selalu melakukan tabayyun atau klarifikasi terhadap datangnya berita. Bahkan klarifikasi ini juga amat ditujukan terhadap para tokoh agama agar selalu mengawal datangnya beritaberita dan diklarifikasi kebenarannya.
\end{abstract}

Kata Kunci: Hoax, Sosial Media, Al-Qur'an 


\section{PENDAHULUAN}

Dunia yang begitu besar dan jarak antara negara satu dengan yang lainnya tidak lagi menjadi penghalang buat seseorang untuk mengetahui apa yang terjadi di belahan dunia lainnya. Hal ini tentu disebabkan oleh efek kecepatan menerima arus informasi dan komunikasi melalui teknologi electronic digital (internet). Paul Virrilio pada konteks ini menyatakan, batas waktu juga menjadi tidak berarti, ia menyebutnya sebagai teori Dromologi. Menurutnya, teknologi telah menghancurkan batas-batas ruang dan waktu/kecepatan. ${ }^{1}$ Misalnya saat ini seseorang bisa berkomunikasi dengan teman atau koleganya di wilayah maupun belahan bumi mana pun dalam hitungan detik dan hal itu menggantikan waktu tempuh yang mungkin bisa mencapai puluhan jam.

Konsekuensi logis atas perkembangan teknologi electronic digital memberikan dampak positif sekaligus negatif terhadap perilaku sosial, budaya, ekonomi maupun politik. Salah satu contoh mengenai apa yang hari ini kita sebut sebagai media sosial (facebook, twitter, youtube, instagram, whatshapp, dan lain-lain). Bagi pelaku bisnis atau pengusaha, keberadaan medsos dapat memberikan dampak positif yang signifikan terhadap penjualan. Media sosial juga sering dijadikan alat meyatakan kebebasan berpendapat bahkan hanya sekedar memenuhi kebutuhan mengaktualisasikan diri. ${ }^{2} \mathrm{Hal}$ ini disebabkan karena medsos menyediakan ruang public yang dengan mudah diakses oleh semua orang di belahan dunia manapun untuk berkomunikasi atau berinteraksi.

Namun jika kita melihat sisi negatifnya, tidak kalah dahsyat efek yang ditimbulkan akibat penyalahgunaan dari media sosial. Misalnya, bagaimana seseorang dapat menciptakan kebohongan (hoax) atau propaganda yang dapat menyebabkan terjadinya konflik maupun chaos melalui media social?. ${ }^{3}$ Salah satu jawaban yang mungkin bisa kita pelajari dari berbagai fenomena yang sering terjadi saat ini adalah melalui media sosial, seseorang dapat menyembunyikan identitas aslinya atau memiliki akun palsu (anonym),

Sedangkan menurut Khanis Suvianita, maraknya peredaran berita hoak tidak dapat dilepaskan dari orang atau pihak yang bertindak sebagai pembuat atau penyebar berita hoak itu sendiri. Dilihat dari sisi psikologis, pembuat dan penyebar berita hoak adalah pribadi yang ingin dikenal dan diakui keberadaannya oleh orang lain, melalui sesuatu

1 Bagi Virrillo, yang termasuk dala mpengertian teknologi di sini adalah transportasi, komunikasi, telekomunikasi, komputerisasi, dan sebagainya. Namun, majunya sarana komunikasi dan telekomunikasi adalah teknologi yang paling penting dan berperan dalam mendukung hancurnya batas ruang dan waktu tersebut. Lihat, Goerge Ritzer, Teori Sosial Postmodern, terj.Nurhadi, (Yogyakarta: KreasiWacana, 2010), h. 230-231.

2 Aktualiasi Diri merupakan salah satu kebutuhan manusia menurut konsep Piramida hirarkikebutuhanmaslow. Lihat, Sobur Alex, Psikologi Umum, (Bandung: Pustaka Setia, 2003), h. 274

${ }^{3}$ Salah satu contoh kasus yang menyita perhatian public adalah informasi hoax penculikan anak yang terjadi di Lombok, Kalimantan dan beberapa daerah lainnya, menyebabkan orang tak bersalah tewas di adili warga akibat berita hoax. Lihat, https://nasional.tempo.co/read/855222/gara-garahoax-penculik-anak-gelandangan-dikeroyok-di-pantura, diakses pada tanggal 20/01/2018.

182 | Al-Fanar: Jurnal Ilmu Al-Qur'an dan Tafsir 
yang ia hasilkan atau bagikan. ${ }^{4}$

Hasil survei yang dilakukan pada 7 Februari 2017 oleh Masyarakat Telematika Indonesia (Mastel) merilis survei tentang informasi palsu (hoax) yang tengah marak di Tanah Air, diketahui media sosial menjadi sumber utama peredaran hoax. Berita hoax telah tersebar di situs-situs internet sebanyak 34,9 persen, televisi 8,7 persen, media cetak 5 per-sen, email 3,1 persen dan radio 1,2 persen. ${ }^{5}$

Informasi ini menunjukkan bahwa Indonesia tergolong sebagai salah satu negara yang mengalami masalah serius dalam penyebaran hoax. Penyebaran berita hoax mudah terjadi, terutama di masyarakat yang tingkat literasinya masih rendah. Mereka mudah menerima informasi begitu saja tanpa melakukan pengecekan, bahkan menyebarkannya tanpa mempertimbangkan tingkat akurasi informasi yang diterimanya. Masyarakat akhirnya terjerumus dalam kesimpangsiuran berita, provokasi dan rasa saling curiga.

Menanggapi permasalahan tersebut, maka dianggap penting dan mendesak untuk dilakukan kajian yang lebih mendalam mengenai perspektif Al-Qur'an tentang fenomena penyebaran informasi palsu (Hoax). Kajian ini penting dilakukan mengingat Al-Qur'an merupakan rujukan utama kaum muslim, terlebih muslim di Indonesia yang merupakanmayoritas di dunia. Oleh karena itu, menggali nilai-nilai perennial yang terkandung dalam Al-Qur'an terhadap fenomena aktual seperti hoax tersebutmerupaka nsebuahhalkeharusan. ${ }^{6}$

Dalam upaya memahami ayat-ayat yang berkaitan dengan penyebaran Hoax dalam Al-Qur'an dan Hadis, penulis menggunakan metode tematik ${ }^{7}$ berdasarkan topik atau subjek dengan menggali ayat-ayat yang berkaitan dengan penyebaran hoax dalam AlQur'an dan Hadis. Pendekatan dengan metode ini diharapkan dapat mengungkapkan pesan moral melalui ayat-ayat yang berkaitan dengan informasi hoax dan diharapkan dapat memberikan pemahaman di kalangan masyarakat Islam tentang bahaya hoax.

\section{PERILAKU HOAX DI SOSIAL MEDIA}

Dalam bahasa Indonesia, hoax merupakan istilah/kata serapan yang semakna dengan "berita bohong". Hoax diartikan sebagai upaya memperdaya banyak orang dengan sebuah berita bohong (deceive somebody with a hoax); memperdaya beberapa/ sekumpulan orang dengan membuat mereka percaya pada sesuatu berita yang telah

\footnotetext{
${ }^{4}$ Khanis Suvianita (aktivis dan mahasiswi program S3 untuk studi antar agama) dalam diskusi yang diadakan di Surabya menyampaikan "secara natural seseorang ingin di-recognize, ingin diketahui, ingin dilihat. Demokrasi yang berkawin dengan sosial media itu memberi ruang, karena saya bisa mengcreated berita, saya bisa meng-created narasi, cerita, lalu saya bisa membagikannya, atau saya mendapat dari mana dan saya membagikannya. Kemudian orang ingin di-confirm bahwa dia betul, bahwa dia benar, kadang-kadang kisah yang saya buat itu untuk mengatakan bahwa saya benar. Lihat https://www.voaindonesia.com/a/berita-hoaks-ancaman-serius-persatuan-bangsamemasuki-tahun-politik/4553726.html, diakses pada tanggal 20/01/2018.

${ }^{5}$ Andina Librayanti, "Survei: Media Sosial Jadi Sumber Utama Penyebaran Hoax," Liputan 6.com, http://tekno.liputan6.com/read/2854713/survei-media-sosial-jadi-sumber-utama-penyebaranhoax, diakses pada 20/01/2018,

${ }^{6}$ Anne K. Rasmussen, Women The Recited Qur'an, and Islamic Music In Indonesia (London: University Of California Press Ltd, 2010), h. 74

${ }^{7}$ Moh. Quraish Shihab, Tafsir Qur'an dengan Metode Maudu'i, dalam; KH. Bustami A. Gani dan H. Chatib Umam, Ed., Beberapa Aspek llmiah tentang Qur'an, (Jakarta: Pustaka Litera antar Nusa, Cet. II, 1994), h. 27
} 
dipalsukan. ${ }^{8}$ Hoax juga dapat difahami dengan "to deceive someone by making them believe something which has been maliciously or mischievously fabricated" (memperdaya beberapa orang dengan membuat mereka percaya sesuatu yang telah dipalsukan). Sedangkan dalam bentuk kata benda, hoax diartikan sebagai "trick played on somebody for a joke" (bermain tipu muslihat dengan orang lain untuk bercanda) atau "anything deliberately intended to deceive or trick" (apapun yang dengan sengaja dimaksudkan untuk menipu orang lain). ${ }^{9}$

Kemunculan hoax tak lepas dari laju perkembangan teknologi informasi dan komunikasi yang memungkinkan seseorang terkoneksi dengan orang lain lintas teritori dan waktu serta membentuk sebuah ruang semu yang disebut dengan ruang maya. Keberadaan perangkat-perangkat seperti PC, laptop dan gadget yang tersambung dengan internet, menciptakan berbagai macam layanan aplikasi yang memanjakan manusia untuk mengakses informasi dan berkomunikasi melampaui batas-batas Geografis. Mc Luhan menyebutnya dengan istilah Global Village, dimana seseorang dapat menjelajah wilayah yang sangat jauh meskipun hanya duduk di sebuah ruangan yang terbatas. ${ }^{10}$

Kecepatan alat-alat komunikasi, secara substansial telah mengubah cara komunikasi antara masyarakat dan individu. Sebuah komunikasi dan informasi dapat tersebar secara cepat, bahkan tidak ada batasan tertentu, sehingga semua masyarakat bebas mengeluarkan pendapat. Semua menjadi lebih mudah dalam menerima, berbagi, dan memberi komentar melalui media social. Informasi kemudian saling bertumpuk, berimplosif, dan bereksplosif, karena direproduksi melalui opsi bagi (share) dan salin (copy) dalam sistem media sosial. ${ }^{11}$

Kebebasan mengeluarkan berita ini secara tidak langsung kemudian menyebabkan merebaknya berita hoax dalam rangka membentuk opini publik. ${ }^{12}$ Demi kepentingan tertentu, berita hoax bisa digunakan untuk saling menyerang, menuduh, melakukan stereotypes, bahkan untuk mengklaim bahwa sebuah kelompok atau pun agama tertentu yang paling unggul dibandingkan yang lainnya. ${ }^{13}$

${ }^{8}$ Oxford University, Oxford: Learner's Pocket Dictionary (London: Oxford University Press, 2018), h. 211.

9 "Hoax," Wiktionary, diakses pada 20/01/2018, https://en.wiktionary.org/wiki/hoax\#English.

${ }^{10} \mathrm{Mc}$ Luhan mengistilahkan fenomena ini sebagai mechanical technology dan elektrik, atau dalam istilah kita saat ini adalah internet. Semboyannya yang paling terkenal adalah "Medium is the message". Medium atau sarana yang mempengaruhi manusia, bukan isi (content) apa yang disampaikan. Karakteristik medium sebenarnya adalah makna dari pesan itu sendiri sedangkan isi pesan menjadi hal yang 'nothing'. Lihat, Marshall McLuhan, Understanding Media, The Extensions of Man, (Mentor Book: 1964), h. 9. Lihat juga, Jay W. Jensen Rivers and Theodore Peterson, Media Massa Dan Masyarakat Modern, terj. Haris Munandar (Jakarta: Kencana, 2008), h. 346. Global Village berarti dengan perantaraan media komunikasi modern, memungkinkan berjuta-juta orang di seluruh dunia merasakan kedekatan antara satu dan yang lain dalam sebuah lingkaran, lihat Little John, Theories of Human Communication, Fifth (New York: Wadsworth Publishing Company, 1996), h. 324 .

${ }^{11}$ Ratna Istriyani and Nur Huda Widiana, "Etika Komunikasi Islam dalam Membendung Informasi Hoax di Ranah Publik Maya", Jurnal Ilmu Dakwah, Vol. 36. No. 2, 2016, h. 296.

${ }^{12}$ David Holmes, Teori Komunikasi: Media, Teknologi, dan Masyarakat (Yogyakarta: Pustaka Pelajar, 2012), h. 103

${ }^{13}$ Benedictus Simangunsong, "Interaksi Antar manusia melalui Media Sosial Facebook Mengenai Topik Keagamaan,” Jurnal Aspikom Vol. 3, no. 1 (18 Juli 2016), h. 65.

184 | Al-Fanar: Jurnal Ilmu Al-Qur'an dan Tafsir 
Media hadir menyampaikan sebuah informasi yang tak terlepas dari berbagai kepentingan sosial dan politik. Pada akhirnya, media menjadi wadah bias kepentingan berbagai pihak. ${ }^{14}$ Di satu sisi, media sudah menjadi komoditas informasi untuk memenuhi kebutuhan dan keingintahuan masyarakat. Namun, di sisi lain media juga cenderung digunakan untuk kepentingan mendiskreditkan salah satu pihak demi keuntungan tertentu. Itu semua dilakukan tanpa memerhatikan dampak sosial yang mungkin terjadi. ${ }^{15}$

\section{MOTIVASI SESEORANG MENYEBARKAN HOAX}

Mengutip pernyataan Hunt dan Matthew, motivasi seseorang melakukan penyebaran berita bohong disebabkan oleh dua hal: ${ }^{16}$ Pertama adalah motif uang, misalnya, "news articles that go viral on social media can draw significant advertising revenue when users click to the original site". Artikel berita yang viral di media sosial dapat menarik iklan dan penyedia berita untuk mendapatkan keuntunganmelalui situs asalnya. Ini tampaknya telah menjadi faktor utama sebagian besar produsen untuk mencari keuntungan dari adanya berita hoax yang memang dibuat dengan sengaja. ${ }^{17}$

Kedua,motif ideologi, "Some fake news provider seek to advance candidates they favor" (beberapa penyedia berita hoax berusaha untuk mendukung kandidat yang mereka sukai dengan menyerang kelompok oposisi yang menjadi rivalnya). ${ }^{18}$ Contohnya yang belum lama initerjadi di tahun politik Indonesia, demi membela salah satu pasangan Capres, para pendukung fanatik menyebarkan informasi palsu kompetitornya kepada public. Hasil survei Mafindo (Masyarakat Anti Fitnah Indonesia) dalam keterangan rilisnya mencatat, sebanyak 230 hoaks yang terklarifikasi sebagai disinformasi selama periode Juli-September 2018. Rinciannya, hoaks pada Juli 2018 sebanyak 65 konten, Agustus 2018 sebanyak 79 konten, dan meningkat menjadi 107 konten pada September $2018 .{ }^{19}$

Selanjutnya, munculnya berita hoax ini juga tak lepas dari beberapa alasan. Pertama, turunnya pemasukan di media industri yang disebabkan oleh kemudahan membuat website serta lahan untuk konten platform periklanan. Kedua, adanya rasa khawatir akan turunnya reputasi media masa, sehingga untuk meningkatkan reputasi tersebut memunculkan berita hoax yang menghebohkan sebagai ajang meningkatkan reputasi. Ketiga, munculnya media sosial, selain menjadi alat komunikasi modern,

${ }^{14}$ Joko Tri Haryanto, "Etika Islam Tentang Pemberitaan Politik di Indonesia," Yudisia, Vol. 6, no. 1 (2015), h. 48 ,

${ }^{15}$ Istriyani, Media: Causes and Strategies to Overcome Islamophobia (Psychological and Sociological Study), h. 203.

${ }^{16}$ Hunt Allcott dan Matthew Gentzkow, "Social Media and Fake News in the 2016 Election," Journal of Economic Perspectives, Vol. 31, no. 2, 2017, h. 217.

${ }^{17}$ Samanth Subramanian, "Inside the Macedonian Fake-News Complex," Wired, diakses pada 20/01/2018, https://www.wired.com/2017/02/veles-macedonia-fake-news/.

${ }^{18}$ Caitlin Dewey, "Facebook Fake-News Writer: I Think Donald Trump is in the White House because of Me, (Washington Post, November 2016).

${ }^{19}$ Sarana yang paling banyak digunakan untuk menyusun hoaks itu, yakni narasi dan foto $(50,43 \%)$, narasi $(26,96 \%)$, narasi dan video $(14,78 \%)$, dan foto $(4,35 \%)$. Dari jumlah tersebut, hoaks paling banyak disebarkan di Facebook (47,83\%), Twitter (12,17\%), Whatsapp (11,74\%), dan Youtube (7,83\%). Lihat, https://katadata.co.id/berita/2018/10/16/mafindo-catat-hoaks-politikmerajalela-jelang-pilpres-2019 
juga menjadi ajang pencarian uang. Dengan memunculkan berita yang menghebohkan, daya jual media sosial akan semakin banyak menghasilkan keuntungan. Keempat, terus menurunnya "kepercayaan" dari media industri, sehingga memunculkan berita hoax sebagai alternatif untuk mendapatkan daya tarik yang lebih. Kelima, munculnya faktor politik sebagai ajang untuk menurunkan popularitas kelompok lain. ${ }^{20}$

Di Indonesia, beberapa faktor tersebut, telah berusaha ditanggulangi oleh Kementerian Komunikasi dan Informasi seperti tampak pada pemblokiran dua kelompok besar penyebar berita hoax. Pertama, akun-akun pribadi dari kelompok partai politik yang gigih menyajikan berita untuk kepentingan kelompoknya. Kelompok ini ialah Portal Piyungan (eks PKS Piyungan), VOA Islam dan Era Muslim yang belum lama ini telah diblokir oleh Kemenkominfo. Data World Traffic menunjukkan, situs Piyungan sebelum diblokir dikunjungi sebanyak 300 ribu orang perhari, dan telah menghasilkan iklan $\$ 100$ perhari, setara dengan Rp.485 juta setahun. Kedua, situs-situs yang memang mencari penghasilan dari berita-berita hoax yang provokatif dan kontroversial, seperti Posmetro, Nusanews dan NBC Indonesia.

Selain itu, munculnya wadah media sosial seperti Facebook dan Twitter juga menjadi sarana masyarakat untuk menerima dan menyebarluaskan berita dan informasi, baik berupa gambar atau video. Dalam hitungan detik, berita hoax dapat tersebar di seluruh lapisan masyarakat dunia. Mudahnya menyebarluaskan berita juga menjadi pendukung yang paling efektif dalam menyebarkan hoax, terlebih melalui media sosial yang tanpa batas dan tanpa memberikan identitas, sehingga mereka dapat mengungkapkan apa yang diinginkannya secara bebas. Hal inilah yang menyebabkan ketika ada isu yang belum tentu benar, seseorang kemudian menyebarkannya begitu saja. Ditambah lagi keadaan masyarakat Indonesia saat ini cenderung senang berbagi informasi melalui media sosial seperti Whatsap, Blakberry Messangger, Facebok, Twitter, Instagram dan sebagainya dengan tanpa menelusuri berita yang benar. ${ }^{21}$

\section{DAMPAK PENYEBARAN HOAX}

Merebaknya beritahoax di media sosial, telah memberikan dampak negatif yang sangat signifikan, dintaranya: Pertama, merugikan masyarakat, karena berita-berita hoax berisi kebohongan besar dan fitnah. Kedua, memecah belah publik, baik mengatasnamakan kepentingan politik maupun organisasi agama tertentu. Ketiga, memengaruhi opini publik. Keempat, menjadi profokator untuk memundurkan masyarakat. ${ }^{22}$ Kelima, berita-berita hoax sengaja dibuat untuk kepentingan mendiskreditkan salah satu pihak, ${ }^{23}$ sehingga bisa mengakibatkan adu domba terhadap sesama umat Islam. Keenam, sengaja ditujukan untuk menghebohkan masyarakat, sehingga menciptakan ketakutan terhadap masyarakat.

Dengan berbagai dampak negatif yang ditimbulkan akibat adanya peredaran

${ }^{20}$ Morris P. Fiorina dan Samuel J. Abrams, "Political Polarization in the American Public," Annual Review of Political Science, Vol. 11, No. 1 Juni 2008, h. 563-588

${ }^{21}$ Nabila Tasandra, "Penyebaran Hoax dan Budaya Berbagi," Kompas.com, http://nasional. kompas.com/read/2017/02/14/09055481/media.sosial.penyebaran.hoax.dan.budaya.berbagi, diakses pada $20 / 01 / 2018$.

${ }^{22}$ Komunika, “Etika Jurnalistik Perspektif Al-Qur'an,” Limmatus Sauda 7, no. 1 (2013), http:// ejournal.iainpurwokerto.ac.id/index.php/komunika/article/view/373

${ }^{23}$ Istriyani, Media: Causes and Strategies to Overcome Islamophobia (Psychological and Sociological Study), h. 203.

186 | Al-Fanar: Jurnal Ilmu Al-Qur'an dan Tafsir 
hoax tersebut, maka masyarakat awam akan sangat dirugikan. Upaya untuk meminimalkan tentu sangat diharapkan agar masyarakat kembali sadar dan berhati-hati.

\section{ISYARAH AL-QUR'AN MENGENAI HOAX}

Istilah berita bohong (hoax) dalam Al-Quran bisa diidentifikasi dari pengertian kata al-Ifk yang berarti keterbalikan (seperti gempa yang membalikkan negeri), tetapi yang dimaksud di sini ialah sebuah kebohongan besar, karena kebohongan adalah memutarbalikkan fakta. Sedangkan munculnya hoax (sebuah kebohongan) disebabkan oleh orang-orang pembangkang. Dalam hal ini, AlQuran mengistilahkannya dengan' usbah (عصبة). Kata 'usbah diambil dari kata 'asaba (عصب) yang pada mulanya berarti mengikat dengan keras. Dari asal kata ini lahir kata muta'asib (متعصّّب) yakni fanatik. Kata ini dipahami dalam arti kelompok yang terjalin kuat oleh satu ide, dalam hal ini menebarkan isu negatif, untuk mencemarkan nama baik. ${ }^{r \varepsilon}$

Adapun pelaku hoax sendiri biasanya memang sudah diniatkan dengan maksud tertentu. Dalam hal ini, Al-Quran menyebutnya iktasaba (اكتسب) . Iktasaba menunjukkan bahwa penyebaran isu itu dilakukan dengan sungguhsungguh. Ini bukan saja dipahami dari kata kasaba yang mengandung makna usaha, tetapi juga dari tambahan huruf $t a{ }^{\prime}\left(\right.$ ) dalam kata tersebut. ${ }^{\text {ro Kata }}$ (كبره) kibrahu terambil dari kata (كبر) kibr atau kubr yang digunakan dalam arti yang terbanyak dan tersebar. Yang dimaksud disini adalah yang paling banyak dalam menyebarkan berita hoax. ${ }^{r}$

Fenomena tersebarnya berita bohong sendiri sebenarnya sudah dijelaskan dalam Al-Qur'an, sebagaimana dalam QS. an-Nur ayat 11. Menurut sebuah riwayat, munculnya QS. an-Nur ayat 11 tak lain karena adanya tuduhan zina yang ditujukan kepada Aisyah ketika ia akan pulang menuju Madinah bersama pasukan Muslimin. Kemudian di sebuah perjalanan, Aisyah merasa kehilangan kalungnya, Namun, saat Aisyah mencari kalung yang hilang tersebut, pasukan Muslim malah meninggalkannya dan mengira Asiyah sudah bersama mereka. ${ }^{27}$ Pada saat itulah Aisyah merasa tertinggal. Ia kemudian kebingungan. Aisyah pun tertidur akibat rasa kantuknya. Setelah beberapa lama, kemudian seorang sahabat bernama Safwan bin al-Mu'attal Al-Sulami Al-Dhakwani melihatnya. Ia melihat istri Nabi saw. tersebut. Safwan mengucap lafal innalillahi dan kemudian mengantarkan Aisyah hingga sampai kepada rombongan kaum Muslim. Namun, setelah terjadinya peristiwa ini, beberapa dari umat Islam malah ramai-ramai membicarakan dan menyebarkan berita bohong tentang Asiyah. Hingga selama sebulan Aisyah merasakan ada yang beda dari Rasulullah SAW dalam menyikapinya, bahkan hendak mendiskusikan untuk meceraikan Aisyah atas hal ini. Aisyah terus mengeluh dan mengadu kepada

${ }^{24}$ M. Quraish Shihab, Tafsir Al-Misbah: Pesan, Kesan dan Keserasian Al-Quran, vol.9 (Jakarta: LenteraHati, 2002), h. 296.

${ }^{25}$ M. Quraish Shihab, Tafsir Al-Misbah, h. 297.

${ }^{26}$ M. Quraish Shihab, Tafsir Al-Misbah, h. 298

${ }^{27}$ Majid bin Khanjar al-Bankani, Perempuan-perempuan Shalihah: Kisah, Teladan dan Nasihat dari Kehidupan Para Shabiyah Nabi saw, terj. Imam Firdaus (Solo:Tinta Medina, 2013), h. 20-21. 
Allah tentang apa yang telah terjadi, hingga turunlah QS. An-Nur 24: 11 yang menjawab kegelisahannya. ${ }^{28}$

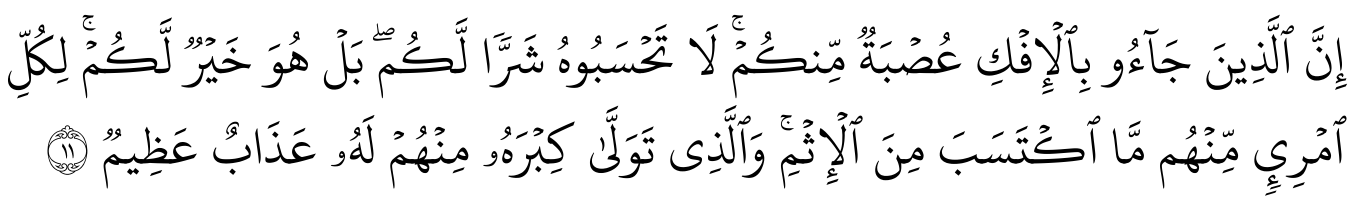

"Sesungguhnya orang-orang yang membawa berita bohong adalah golongan kamu, Jang-anlah kamu menganggapnya buruk bagi kamu, bahkan ia adalah baik bagi kamu, tiap-tiap orang dari mereka memperoleh apa yang dia kerjakan dari dosa itu, dan siapa yang mengambil bagian yang terbesar di dalamnya di antara mereka, bagian azab yang besar" (QS. an-Nur 24: 11)

Ayat ini merupakan kecaman, bagi orang-orang yang menuduh istri Nabi saw. Aisyah, tanpa bukti-bukti. Kemudian Allah berfirman,

Sesungguhnya orang yang membawa dan menyebarluaskan berita bohong dengan sengaja, berita bohong itu menyangkut kehormatan keluarga Nabi Muhammad saw., itu adalah golongan dari komunitas kamu (hidup ditengah kaum mukmin). Janganlah kamu menganggapnya baik atau buruk, karena dengan demikian kamu dapat membedakan siapa yang munafik dan siapa yang kuat imannya (akan mendapatkan balasan yang sesuai). ${ }^{29}$

Dari penjelasan dan riwayat di atas, dapat diambil sebuah pelajaran bahwa sebenarnya kasus hoax yang melanda di Indonesia akhir-akhir ini bukanlah sesuatu yang baru. Jauh sebelumnya, pada masa Nabi Muhammad pun sudah beredar serupa berita hoax. Bahkan fenomena ini terjadi pada keluarga Nabi Muhammad sendiri. Menanggapi hal itu, Allah memberikan sebuah jawaban kepada umat Islam untuk tidak berbuat dalam kerugian (menyebarkan berita bohong), dalam ayat selanjutnya, AlQuran juga menjelaskan kembali ancaman dan bahaya bagi orang-orang yang terlibat dalam penyebaran berita bohong tersebut.

"Mengapa di waktu kamu mendengarnya orang-orang mukminin dan mukminat tidak bersangka baik terhadap diri mereka dan berkata: "ini adalah satu dari berita bohong yang nyata." (QS, an-Nur 24: 12)

Ayat ini menjelaskan, bahwa ketika berita hoax itu tersebar, namun ada di antara kaum Muslimin yang terdiam, tidak membenarkan dan tidak pula membantah. Ada juga yang membicarakannya sambil bentanya-tanya, dan ada pula yang tidak memercayainya dan menyatakan kepercayaan tentang kesucian Aisyah. Sehingga ayat ini diturunkan untuk memberikan peringatan kecaman terhadap orang-orang yang diam seakan membenarkan, apalagi yang membicarakan sambil bertanya-tanya tentang kebenaran isu itu. Ayat ini menganjurkan mereka untuk melakukan langkah positif, mengapa di waktu kamu mendengarnya (berita bohong), kamu selaku orang-orang mukminin dan mukminat tidak berprasangka baik terhadap saudara-saudara mereka yang dicemarkan namanya, padahal yang dicemarkan itu adalah bagian dari diri mereka sendiri, bahkan menyangkut Nabi saw. dan keluarga beliau. Dan mengapa mereka tidak berkata, bahwa ini adalah suatu kebohongan yang nyata, karena mereka mengenal siapa Aisyah ra. ${ }^{30}$

${ }^{28}$ Imadu ad-din Abu al-Fida Isma'il Ibnu Kathir, Tafsir Al-Qur'an Al- 'Azim, juz 3 (Damaskus: Maktabah Dar al-Fiha', 1994), h. 276-277

${ }^{29}$ Qurais Shihab, Tafsir Al-Misbah Pesan, Kesan dan Keserasian Al-Quran, h. 294

${ }^{30}$ Qurais Shihab, Tafsir Al-Misbah Pesan, Kesan dan Keserasian Al-Quran, h. 299 
Selanjutnya, lagi-lagi Al-Qur'an juga mengecam umatnya yang ikut andil dalam menyebarkan berita hoax padahal ia belum tahu kebenaran dari sebuah berita tersebut.

"Dan seandainya bukan karena karunia Allah dan rahmat-Nya kepadamu di dunia dan akhirat, niscaya kamu akan ditimpa azab yang besar, disebabkan oleh pembicaraanmu tentang (berita bohong) itu, ingatlah ketika kamu menerima (berita bohong) itu dari mulut ke mulut dan kamu katakan dari mulutmu itu apa yang tidak kamu ketahui sedikitpun, dan kamu menganggapnya remeh, padahal dalam pandangan Allah itu suatu perkara yang besar." (QS. An-Nur 24: 14-15).

Dari penjelasan ayat ini, jelas bahwa ancaman Allah betul-betul ditujukan kepada orang-orang yang terlibat dalam menyampaikan berita hoax, baik orang-orang yang sudah mengetahui berita hoax itu sendiri maupun belum mengetahuinya, istilah ini jika dianalogikan pada zaman sekarang berarti orang-orang yang ikut menshare berita-berita heboh yang belum tentu kebenaranya, bahkan tahu kevalidan atau tidak, apabila seseorang tersebut ikut andil dalam menyampaikan berita hoax, maka ia juga patut mendapatkan ancaman azab Allah Karena walaupun perkara itu terlihat remeh, tapi Allah menganggap perkera itu besar, karena perkara ini sangat berkaitan dengan menghancurkan keharmonisan hubungan sesama umat Islam.

Di dalam hadis tidak di jelaskan secara spesifik mengenai hoax, namun lebih pada antisipasi atau langkah prefentif agar setiap orang tidak dengan mudahnya menyebarkan informasi terkait berita yang didengarnya. Hal ini dikarenakan pintu masuk yang dapat mengantarkan seseorang dengan mudah menyebarkan segala berita yang diketahui tanpa memastikan kebenaran berita tersebut. Nabi Muhammad saw telah memperingatkan kita dalam sabdanya:

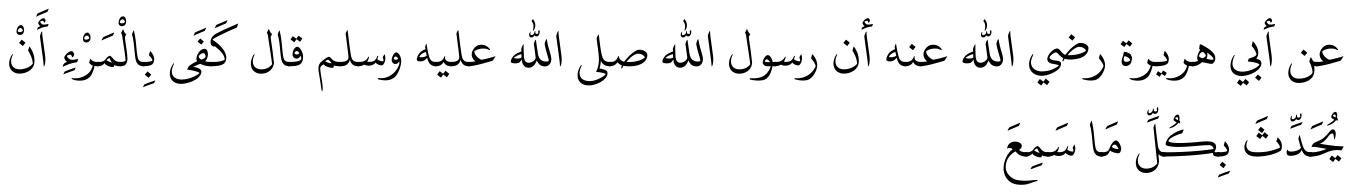

Dari Abu Hurairah radhiallahu'anhu, ia berkata: telah bersabda Rasulullah shallahu 'alaihi wasallah: "Cukup seseorang telah berdusta dengan menceritakan setiap apa yang di dengar". ${ }^{31}$

Menurut ibnul Jauzy, terdapat dua penafsiran terhadap hadis diatas, pertama maksudnya adalah dia tahu jika berita itu bohong namun ia tidak menjelaskannya, maka sudah termasuk bagian orang yang berbohong. Kedua maksudnya adalah seseorang sudah dikatakan berbohong karena tidak setiap berita yang didengar dapat dipercaya. ${ }^{32}$

Sedangkan menurut Imam An Nawawi Asy Syafi'i menjelaskan bahwa:

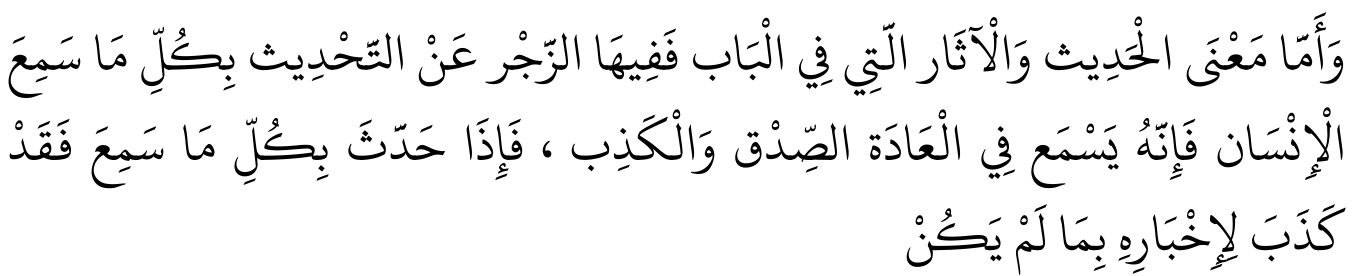

"adapun makna hadis ini dan makna atsar yang semisalnya adalah, larangan

${ }^{31}$ Muslim bin al Hajjaj Abul Husain Al Kusyairy, Al Jami'ash Shohih, (Bairut: Dar Al Jil, tth.), JilidI, hal. 10

32 Abdur Rahman bin 'Aly Abul Faraj Ibnul Jauzy, Kasyful Musykil Min Hadits Shohihain, (Riyadh: DarulWathon, tth.) jilid I, Hhal. 340 
menyampaikan setiap berita yang didengar oleh seseorang, karena yang didengar itu bias saja kabar benar atau kabar bohong, maka jika ia meceritakan setiap yang ia dengar, berarti ia telah berdusta karena menyampaikan sesuatu yang tidak valid". ${ }^{33}$

Hadist ini jika dicermati terkait dengan Bahasa lisan, namun demikian secara kontekstual hadis ini juga mencakup juga Bahasa tulisan. Hadis ini juga memberikan petunjuk bagi kita akan larangan yang bersifat umum baik media cetak, maupun elektronik (medsos).

Rasulullah saw juga memberi peringatan terhadap orang yang bermain-main dengan perkataan beliau, sebagaimana yang diriwayatkan oleh HR. Muslim:

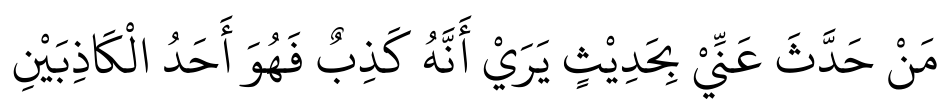

"Barang siapa menceritakan sebuah berita dariku yang dia ketahui bahwa berita itu adalah bohong maka orang tersebut termasuk diantara dua pendusta". ${ }^{34}$

\section{RESPON AL-QUR'AN DALAM MENYIKAPI BERITA HOAX}

Sejarah Islam mencatat, bahwa fenomena hoax juga sudah sering merugikan umat Islam, terlebih malah sudah berusaha memasuki teks suci Al-Quran, namun tidak berhasil, karena Allah telah menjamin keaslian Al-Quran. Akan tetapi, kebohongan telah menyusup ke dalam penafsiran Al-Quran. Makna Al-Quran pernah disimpangkan untuk kepentingan pribadi atau golongan. ${ }^{35}$ Menanggapi hal itu, peran Al-Quran sebagai pedoman umat Islam perlu didialogkan kembali kepada masyarakat Islam guna menyikapi hal ini, karena wawasan Al-Quran telah mengatur berbagai hal, terlebih dalam menyikapi dan meminimalisir peredaran hoax yang begitu sangat meresahkan, beberapa an-juran Al-Quran terkakat upaya meminimalisir peredaran hoax tersebut, sebagaimana berikut.

1. Al-Quran mengajurkan untuk selalu berkata benar

Al-Quran telah memberikan penjelasan kepada umat manusia agar selalu berkata benar, terlebih dalam menyampaikan sebuah berita, karena dengan menyampaikan sebuah berita yang benar, akan menjaga kemurnian ajaran Islam serta akan melahirkan keharmonisan dalam pergaulan. Sebagaimana dijelaskan dalam Al-Quran tentang keharusan untuk menyampaikan kebenaran, hal ini sebagai-mana dijelaskan dalam QS. al-Ahzab 33: 70-71.

Hai orang-orang yang beriman, bertaq-walah kamu kepada Allah dan sampaikanlah perkataan yang benar. Allah akan memperbaiki bagi amalan-amalanmu dan mengampuni bagi dosa-dosamu. Dan barang siapa yang mematuhi Allah dan Rasul-Nya maka ia akan memperoleh suk-ses yang besar. (QS. Al-Ahzab 33: 70-71).

Maksud dari ayat ini ialah, Allah memberikan peringatan kepada umat manusia, bahwa takutlah kalian untuk berbuat maksiat (berkata dusta dalam menyampaikan berita), karena dengan berbuat maksiat (menyampaikan berita dengan dusta), maka Allah akan memberikan hukuman, selanjutnya ayat ini juga merupakan seruan kepada

${ }^{33}$ Muhammad bin Syaraf an Nawawi, al Minaj, Syarah Shohih Muslim bin Hajjaj, (Bairut: Dar Ihya At Turats Al 'Araby, 1392), Jilid I, hal. 75

${ }^{34}$ Muslim bin al Hajjaj Abul Husain Al Kusyairy, Al Jami' ash Shohih. hal. 8

${ }^{35}$ Al-Shafi'i, Al-Umm, Jilid 1. (Beirut: Daw al-Jawad, t.th.), hal. 208. 
umat Islam agar berkata dengan perkataan yang lurus, artinya dalam menyam-paikan sebuah berita seorang mukmin harus menyampaikan berita yang lurus dan tidak menyimpang, sehingga perkataan tersebut tidak menimbulkan kebatilan, dengan berkata yang benar, maka Allah akan memberikan petunjuk kebenaran menuju jalan yang terang benderang. ${ }^{36}$

Orang-orang yang beriman kepada Allah tidak akan berdusta, karena Islam jelas meng-ajarkan untuk menyampaikan kebenaran, baik dari pribadi maupun kelompok/ organisasi, ${ }^{37}$ sehingga dapat menyampaikan sebuah berita dengan penuh kebenaran, karena Islam mengajak masyarakat Muslim untuk menyampaikan kebenaran, ${ }^{38}$ sebagaimana yang dicita-citakan Islam. ${ }^{39}$ Dengan demikian, Islam mengajarkan agar dalam menyampaikan sebuah berita hendaknya disampaikan dengan sesuai petunjuk dan jalan yang benar. ${ }^{40}$ Terlebih dalam hal memberikan informasi Al-Quran telah menyebutnya dengan sebutan qawlan shadidan, yaitu berkata benar atau berkomunikasi dengan baik dalam berinteraksi sosial. ${ }^{41}$ Sehingga, umat Islam dituntut untuk mencapai derajat kebenaran faktualitas dengan melakukan upaya check-recheck, konfirmasi, dan akurasi. ${ }^{42}$ Hal ini untuk menghindari terjadinya defamation (pencemaran nama baik), baik berupa libel (hasutan) maupun slander (fitnah). ${ }^{43}$

Terlebih, melalui Al-Quran Islam mengajarkan umatnya untuk selalu menyampaikan berita dengan benar, karena menyampaikan kebenaran merupakan kunci dalam meraih kebehagiaan dan terhindar dari segala hal yang tidak menentramkan. ${ }^{44}$ Menyampaikan berita benar tersebut berarti berkata benar dengan sebenar-benarnya istilah lainnya adalah menyampaikan berita dengan penuh kejujuran. ${ }^{45}$

2. Melakukan tabayyun setiap menerima berita

Tuntutan umat Islam agar selalu melakukan klarifikasi saat menerima berita sudah diatur dalam Al-Quran. Al-Quran mewajibkan umat Islam untuk melakukan tabayyun.

"Hai orang-orang yang beriman, jika datang kepadamu orang fasik membawa berita maka periksalah dengan teliti (fa tabayyanu), agar kamu tidakmenimpakan suatu musi-bah kepada suatu kaum tanpa megetahui keadaan yang menyebabkan

${ }^{36}$ Abu Ja'far Muhammad bin Jarir Al-Tabari, Tafsir Al-Tabari, Jilid 21 (Cairo: Dar Al-Salam, 2007), h. 274-275.

${ }^{37}$ Muhammad Abu Zahrah, Al-Da'wahlla al-Islam (t.k.: Dar al-Fikr al-'Arabi, t.th..), hal. 33-34

${ }^{38}$ Ali Mahfuz, Hidayat al-Murshidin (Cairo: al-Matba'ah al-Uthmaniyyah al-Misriyyah, 1958), h. $69-70$

${ }^{39}$ Ahmad Ibrahim Mahna, al-Tarbiyah F̄̄ al-Islām (Cairo: Dar al-Sha’b, 1982), h. 49

${ }^{40}$ Muhammad ibn Abi Bakr ibn Abd al-Qadir Al-Razi, Mukhtar al-Sihah (Beirut: Dār al-Kutub al-'Ifmiyyah, 1994), hal. 647

${ }^{41}$ Muh. SyawirDahlan, “Etika Komunikasi dalam Al-Qur'an Dan Hadis,” JurnalDakwahTabligh 5, no. 1 (2014): 115-23, http://journal.uin-alauddin.ac.id/in-dex.php/tabligh/article/view/342.

42 Denis McQuail, Media Performance: Mass Communication and the Publik Interest (New Delhi: Sage Publications, 1992).

43 Deborah Potter, Buku Pegangan Jurnalisme Independen (Jakarta: Biro Program InformasiInternasionalDeplu AS, 2006), h. 60

${ }^{44}$ Ahmad Mahmud Subhi, Al-Falsafah al-Akhlaqiyyah fi al-Fikr al-Islami: al-'Aqliyyunwa al-Dhauqiyyun aw al-Nazarwa al-'Amal, terj.. oleh Yunan Askaruzzaman Ahmad (Jakarta: PT. SerambillmuSemesta, 2001), h. 129.

${ }^{45}$ Bill Kovach dan Tom Rosenstiel, The Elements of Journalism (Jakarta: Yayasan Pantau, 2006), hal. 38 . 


\section{kamu menye-sal atas perbuatan itu." (QS. Al-Hujurat 49: 6).}

Ayat tersebut merupakan anjuran kepada umat Islam yang beriman, agar berhatihati dalam menerima berita yang datangnya dari orang fasik. ${ }^{46}$ Umat Islam dituntut agar selalu berhati-hati, baik dalam menyampaikan berita maupun menjalani kehidupan sehari-hari. Kebenaran identik dengan nilai azali ketu-hanan sehingga Islam menjadi agama yang mengajarkan manusia agar keluar dari kege-lapan menuju cahaya keimanan yang terang benderang, memberikan pedoman dan petunjuk kepada jalan yang lurus. ${ }^{47}$ Islam juga dipahami sebagai agama risalah. Ia harus disampaikan kepada umat manusia sampai akhir hayatnya. ${ }^{48}$

Ayat ini merupakan peringatan kepada umat Islam agar melakukan konfirmasi dan berhati-hati akan datangnya berita dari orang-orang fasik yang bermaksud menyesatkan umat Islam. Karenanya, umat Islam dianjurkan untuk mengoreksi datangnya berita dari orang-orang fasik (yang biasa berbuat kerusakan). Hal ini dilakukan sebagai sebuah upaya mengantisipasi datangnya berita hoax yang akan menyebabkan pertikaian, permusuhan dan penyesalan. ${ }^{49}$

Ayat ini juga menunjukkan adanya penekanan Al-Quran terhadap nilai dasar keimanan dan ketakwaan kepada Allah. Ia diwujudkan ke dalam bentuk implementasi nilai kemanusiaan untuk menyikapi segala berita yang datang dengan memeriksa secara teliti, tidak gegabah, dan tidak tergesa-gesa dalam menerima berita sebelum kebenaran beritanya dianggap jelas. Dengan demikian, melalui ayat ini Allah memberikan pedoman bagi masyarakat agar berhati-hati dalam menerima berita terutama berita bohong yang bersumber dari agen-agen pembawa berita bohong tersebut. Al-Quran berpesan jika ada berita atau informasi yang datang hendaknya terlebih dahulu melakukan tabayyun dengan memeriksa secara teliti berita tersebut. Selain itu, ayat di atas juga menunjukkan adanya penekanan dari Al-Quran terhadap para tokoh agama umat Islam, agar berperan dalam meminimalkan peredaran berita hoax di masyarakat Islam. ${ }^{50}$ Ini penting terkait dengan peranannya sebagai sebagai klarifikasi kebenaran dalam menyampaikan berita. Peran klarifikasi dari seorang tokoh agama ini diharapkan dapat menjadi penjelas dalam memerangi fenomena-fenomena peredaran berita bohong atau hoax saat ini. Dengan demikian, para tokoh agama diharapkan mampu melakukan upaya check-recheck, konfirmasi, dan akurasi ${ }^{51}$ dalam mengawal dan mengklarifikasi se-buah berita, sehingga pesan berita yang tersebar dapat diterima dan dimanfaatkan masyarakat untuk mempelajari realitas yang melingkupi situasi tertentu. ${ }^{52}$

Selanjutnya, para tokoh agama juga mendukung dengan selalu menyampaikan

${ }^{46}$ Aidh Al-Qarni, Tafsir Al-Muyassar (Jakarta: Qisthi Press, 2008), hal. 153.

${ }^{47}$ Muhammad Abd al-'Azim Al-Zarqani, Manahil al-'Irfan Fi ,Ulum Al-Qur $a n$ (Cairo: Isa alBabi aI $\neg$ Halabi, 1972), hal. 124

${ }^{48}$ Mahfuz, Hidayat al-Murshidin, hal. 27

49 Al-Qarni, Tafsir Al-Muyassar, hal. 153

${ }^{50}$ Seruan ayat ini kepada para pemuka agama/tokoh agama, karena pada dasarnya ayat ini diturunkan, berkaitan dengan datangnya orang munafik, sehingga para pemuka agama diharapkan menyampaikan himbauan kepada para umat Islam agar selalu berhati-hati dalam menerima datangnya berita, terlebih jika yang datang tersebut adalah orang-orang munafik yang akan membawa kerusakan dan kebodohan, Lihat, Abu Ja'far Muhammad bin Jarir Al-Tabari, Tafsir Al-Tabari, hal. 716.

${ }^{51}$ Denis McQuail, Media Performance: Mass Communication and the Publik Interest.

${ }^{52}$ Eriyanto, Analisis Framing, Konstruksi, Ideologi dan Politik Media (Yogyakarta: LKiS, 2002). 
dan mencontohkan aktualisasi nilai-nilai keimanan dan ketakwaan kepada Allah. Sebagaimana misalnya, ketika ada berita yang datang dari manapun, para tokoh agama tidak terjebak dalam euforia yang sesat menyesatkan atau malah sebagai agen penguat berita hoax. Keteladanan sifat Rasul seperti shiddiq, amanah, tabligh, dan fathanah yang sekarang ini digantikan harus diaplikasikan dan dicontohkan dalam kehidupan sehari-hari.

\section{Kecaman bagi penyebar Hoax di dalam Al-Quran dan Hadis}

Al-Quran sangat mengecam orang yang ikut andil dalam menyebarkan berita bohong, baik dengan sadar ataupun tanpa sadar menyebarkannya. Hal ini ditegaskan dalam QS. An-Nahl 16:105 dan QS. an-Nur 24: 14-15.

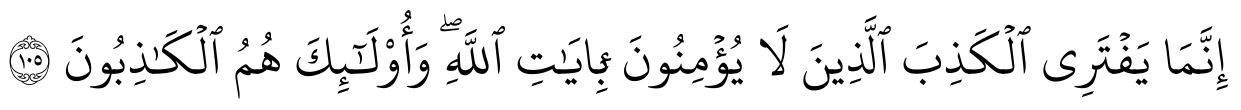

Sesungguhnya yang mengada-adakan kebohongan, hanyalah orang-orang yang tidak beriman kepada ayat-ayat Allah, dan mereka itulah orang-orang pendusta. (QS. An-Nur 24: 14-15).

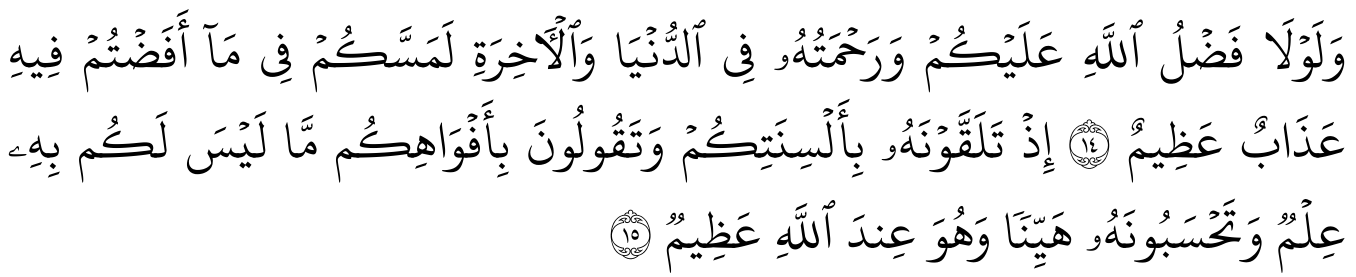

Dan seandainya bukan karena karunia Allah dan rahmat-Nya kepadamu di dunia dan akhirat, niscaya kamu akan ditimpa azab yang besar, disebabkan oleh pembicaraan-mu tentang (berita bohong) itu, ingatlah ke-tika kamu menerima (berita bohong) itu dari mulut ke mulut dan kamu katakan dari mulutmu itu apa yang tidak kamu ketahui sedikitpun, dan kamu menganggapnya remeh, padahal dalam pandangan Allah itu suatu perkara yang besar. (QS. An-Nur 24: 14-15).

Ayat tersebut menjelaskan bahwa Allah tidak akan memberikan karunia dan rahmat kepada orang-orang yang turut ikut andil dalam penyebaran berita bohong, termasuk dalam konteks saat ini adalah hoax. Jika mereka tidak segera untuk bertaubat dan mengakui kesalahannya, maka Allah akan memberikan azab yang besar kepada orang-orang tersebut. Allah menegaskan, apakah kamu menganggap ringan perbuatan yang kamu lakukan dengan menyebar berita-berita bohong tersebut? Jika kamu menganggapnya perkara yang ringan, maka Allah mengang-gapnya sebagai urusan yang besar, karena pe-nyebarannya dapat merugikan berbagai pihak.

Berdasarkan ayat ini, Allah sangat mengecam orang-orang yang yang memproduksi ataupun ikut andil dalam menyebarkan berita bohong. Sebaiknya umat Islam lebih teliti dan berhati-hati dalam menerima dan menyam-paikan berita. Islam mengharuskan umatnya menyampaikan kebenaran, baik secara pribadi maupun kelompok/organisasi. ${ }^{53}$ Umat Islam diharapkan dapat menyampaikan berita dengan baik dan benar, sebagai wujud keimanan dan ketaatan kepada agama, ${ }^{54}$ sebagaimana yang dicita-citakan Islam. ${ }^{55}$ Dengan demikian, Islam mengajarkan agar dalam menyampaikan sebuah berita

\footnotetext{
${ }^{53}$ Zahrah, Al-Da'wahlla al-Islam.

${ }^{54}$ Amrullah Ahmad, Dakwah dan Perubahan Sosial (Yogyakarta: LP3Y, 1984), h. 7

${ }^{55}$ Mahna, al-TarbiyahF̄̄ al-Islām, h. 49
} 
hendaknya disampaikan dengan sesuai petunjuk dan jalan yang benar. ${ }^{56}$

Larangan keras menyampaikan berita hoax juga disampaikan rasulullah dalam sabdanya:

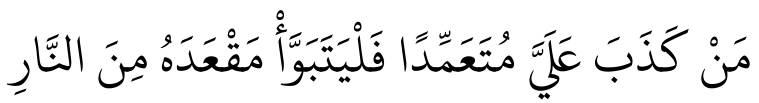

"Barang siapa berdusta atas namaku dengan sengaja, maka hendaknya dia bersiap-siap mengambil tempat di Neraka." (Muttafaq 'alaih)

Para ulama sepakat bahwa sengaja berdusta atas nama Rasulullah Shallallahu 'alaihi wa sallam termasuk dosa besar, bahkan Abu Muhammad al-Juwaini sangat keras sehingga mengkafirkan orang yang sengaja dusta atas nama Rasulullah Shallallahu 'alaihi wa sallam.

\section{PENUTUP}

Penjelasan diatas dapat ditarik kesimpulan bahwa, penyebaran informasi hoax di media sosial merupakan fenomena yang mengancam ukhuwah Islamiyah dalam berbangsa dan bernegara. Keberadaan konten-konten hoax di jagad media social memberikan dampak negative yang signifikan yang berhasil membuat masyarakat terbelah, seperti membuat konten-konten profokatif, propaganda, memutar balikkan fakta. Oleh karena itu, menggali dan memahami nilai-nilai perennial ayat-ayat Al-Quran dan hadis yang berkaitan dengan hoax merupakan sebuah langkah untuk menanggulangi peredaran hoax. Untuk menjawab keresahan hoax pada masa tersebut, Allah mengecam terhadap para pelaku penyebar hoax. Al-Quran juga menganjurkan untuk selalu berkata benar. Ia merupakan perbuatan orang-orang yang patuh kepada Allah. Dengan menjaga perkataan yang benar, maka penyebaran hoax akan semakin minim. Selanjutnya selain berkata benar, Al-Quran dan hadis juga menyuruh umat Islam untuk selalu melakukan tabayyun atau klarifikasi terhadap datangnya berita. Bahkan klarifikasi ini juga amat ditujukan terhadap para tokoh agama agar selalu mengawal datangnya berita-berita dan diklarifikasi kebenarannya. Dengan mengedepankan dan mengikuti langkah-langkah Al-Quran tersebut, tentunya umat Islam harus mengikuti dan meneladani seruan Al-Quran agar dapat mengatasi dan meminimalkan penyebaran hoax yang terjadi saat ini.

\section{DAFTAR PUSTAKA}

Ahmad, Amrullah. Dakwah dan Perubahan Sosial. Yogyakarta: LP3Y, 1984.

Allcott, Hunt, dan Matthew Gentzkow. "Social Media and Fake News in the 2016 Election." Journal of Economic Perspectives 31, no. 2 (Mei 2017): 211-36. doi:10.1257/jep.31.2.211.

Al-Qarni, Aidh. Tafsir Al-Muyassar. Jakarta: Qisthi Press, 2008.

Al-Razi, Muhammad ibn Abi Bakr ibn Abd al-Qadir. Mukhtar al-Sihah. Beirut: Dār alKutub al-'Ifmiyyah, 1994.

Al-Zarqani, Muhammad Abd al-'Azim. Manahil al-'Irfan Fi 'Ulum Al-Qur'an. Cairo: Isa al-Babi aI-Halabi, 1972.

Al-Shafi'i. Al-Umm. 1st ed. Beirut: Daw al-Jawad, t.t.

56 Al-Raziy, Mukhtaral-Sihah, hal. 647

194 | Al-Fanar: Jurnal Ilmu Al-Qur'an dan Tafsir 
Al-Tabari, Abu Ja'far Muhammad bin Jarir. Tafsir Al-Tabari. 21st ed. Cairo: Dar AlSalam, 2007.

Bekker, Anton, dan Achmad Charis Zubair. Metodologi Penelitian Filsafat. Yogyakarta: Kanisius, 1990.

Budiman, Ahmad. "Berita Bohong (Hoax) Di Media Sosial dan Pembentukan Opini Publik." Majalah Info Singkat Pemerin-tahan Dalam Negeri Isu Aktual 9, no. 01 (2017). https://berkas.dpr.go.id/puslit/ files/info_singkat/Info Singkat-IX-1-IP3DI-Januari-2017-181.pdf.

Chang, Christopher, dan M. Eric Gershwin. "Mold Hysteria: Origin of the Hoax." Clinical and Developmental Immunology 12, no. 2 (2005): 151-58. doi:10.1080/ 17402520500131409.

Dahlan, Muh. Syawir. "Etika Komunikasi dalam Al-Qur'an dan Hadis.” Jurnal Dakwah Tabligh 5, no. 1 (2014): 115-23.

Dewey, Caitlin. "Facebook Fake-News Writer: I Think Donald Trump is in the White

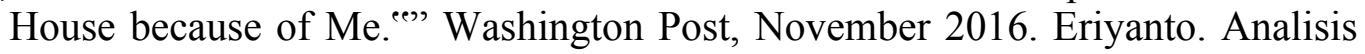
Framing, Konstruksi, Ideologi dan Politik Media. Yogyakarta: LKiS, 2002.

Fiorina, Morris P., dan Samuel J. Abrams. "Political Polarization in the American Public." Annual Review of Political Science 11, no. 1 (Juni 2008): 563-88. doi:10.1146/ annurev.polisci.11.053106.153836.

Firmansyah, Ricky. "Web Klarifikasi Berita Untuk Meminimalisir Penyebaran Berita Hoax." Jurnal Informatika 4, no. 2 (22 September 2017). http://ejournal.bsi. ac.id/ejurnal/index.php/ji/article/view/2138.

Haryanto, Joko Tri. "Etika Islam Tentang Pemberitaan Politik di Indonesia." Yudisia 6, no. 1 (2015): 47-70. http:// journal.stainkudus.ac.id/index.php/Yudisia/article/ view/1471.

Holmes, David. Teori Komunikasi: Media, Teknologi, dan Masyarakat. Yogyakarta: Pustaka Pelajar, 2012.

Ibnu Kathir, Imadu al-din Abu al-Fida Isma'il. Tafsir al-Qur'an al-'Azim. Vol. 2. Damaskus: Maktabah Dar al-Fiha’, 1994.

Istriyani, Ratna. "Media: Causes and Strategies to Overcome Islamophobia (Psychological and Sociological Study)." QIJIS (Qudus International Journal of Islamic Studies) 4, no. 2 (27 November 2016): 201-2017. doi:10.21043/qijis. v4i2.1759.

Istriyani, Ratna, dan Nur Huda Widiana. "Etika Komunikasi Islam dalam Membendung Informasi Hoax Di Ranah Publik Maya", Jurnal Ilmu Dakwah, Vol. 36. No. 2 (2016).

John, Little. Theories of Human Communication. Fifth. New York: Wadsworth Publishing Company, 1996.

Kasperek, Sheila, dan Bethany Messersmith. "The Library that Cried Wolf: Outcomes of a Banned Book Hoax on Facebook." Pennsylvania Libraries: Research \& Practice 3, no. 1 (30 April 2015): 53-75. doi:10.5195/PALRAP.2015.87.

Kietzmann, Jan H, Kristopher Hermkens, Ian P. McCarthy, dan Bruno S. Silvestre. "Social media? Get serious! Understan-ding the functional building blocks of social media." Business Horizons 54, no. 3 (Mei 2011): 241-51. doi:10.1016/j. bushor.2011.01.005. 
Koloay, RNS. "Perkembangan Hukum Indonesia Berkenaan dengan Teknologi Informasi Dan Komunikasi." Jurnal Hukum Unsrat 22, no. 5 (2016): 16-27.

Komunika. "Etika Jurnalistik Perspektif Al-Qur'an.” Limmatus Sauda 7, no. 1 (2013).

Kovach, Bill, dan Tom Rosenstiel. The Elements of Journalism. Jakarta: Yayasan Pantau, 2006.

Mahfuz, 'Ali. Hidayat al-Murshidin. Cairo: al-Matba'ah al-Uthmaniyyah al-Misriyyah, 1958.

Mahna, Ahmad Ibrahim. al-Tarbiyah Fū al-Islām. Cairo: Dar al-Sya'b, 1982. McQuail, Denis. Media Performance: Mass Communication and the Publik Interest. New Delhi: Sage Publications, 1992.

Norman, Ishmael D., Moses Aikins, dan Fred Binka. "Earthquake hoax in Ghana: exploration of the Cry Wolf hypothesis." Journal of Public Health in Africa 3, no. 14 (26 April 2012): 52-58. doi:10.4081/ jphia.2012.e14.

Oxford University. Oxford: Learner's Pocket Dictionary. Oxford: Oxford University Press, 2011.

Potter, Deborah. Buku Pegangan Jurnalisme Independen. Jakarta: Biro Program Informasi Internasional Deplu AS, 2006.

Rasmussen, Anne K. Women The Recited Qur'an And Islamic Music In Indonesia. London: University Of California Press Ltd, 2010.

Rivers, Jay W. Jensen, dan Theodore Peterson. Media Massa dan Masyarakat Modern. Diterjemahkan oleh Haris Munandar. Jakarta: Kencana, 2008.

Shihab, M. Quraish. Tafsir Al-Misbah Pesan, Kesan dan Keserasian Al-Quran. Vol. 9. Jakarta: Lentera Hati, 2002.

Simangunsong, Benedictus A. "Interaksi Antarmanusia melalui Media Sosial Facebook Mengenai Topik Keagamaan.” Jurnal Aspikom 3, no. 1 (18 Juli 2016): 65-76. doi:10.24329/aspikom.v3i1.99.

Subhi, Ahmad Mahmud. Al-Falsafah al-Akhlaqiyyah fi al-Fikr al-Islami: al-'Aqliyyun wa al-Dhauqiyyun aw al-Nazar wa al-'Amal. Diterjemahkan oleh Yunan Askaruzzaman Ahmad. Jakarta: PT. Serambi Ilmu Semesta, 2001.

Suwarno, Peter. "Depiction of Common Enemies In Religious Speech: The Role Of The Rhetoric of Identification And Purification in Indonesian Religious Conflicts." Walisongo 21, no. 1 (2013): 1-18.

"Wabah Hoax : Kabar Sesat Di Media Sosial.” Tempo, Januari 2016.

Zahrah, Muhammad Abu. Al-Da'wah lla al-Islam. t.p.: Dar al-Fikr al-'Arabi, t.t. 